\title{
PERANCANGAN PERMAINAN “MEMBUAT BIOETANOL DARI LIMBAH BUAH" MENGGUNAKAN ADOBE FLASH CS3
}

\author{
Nurul Arifa'), Dr. R. Rizal Isnanto,S.T.,M.M.,M.T. ${ }^{2)}$, Dr. Oky Dwi Nurhayati,S.T.,M.T. ${ }^{2)}$ \\ Program Studi Sistem Komputer, Fakultas Teknik, Universitas Diponegoro \\ Jln. Prof. Sudharto, Tembalang, Semarang, Indonesia \\ Email: nurularifa14@yahoo.com
}

\begin{abstract}
Abstrak - Bahan bakar fosil termasuk dalam sumber daya alam yang sulit untuk diperbaharui karena proses pembetukannya yang memakan waktu sangat lama, padahal pada saat ini pemakaian bahan bakar fosil sangatlah tinggi terutama pada sektor transportasi. Diperlukan sebuah pengenalan sejak awal terhadap energi alternatif yaitu bahan bakar nabati seperti bioetanol dari limbah buah. Untuk mengenalkan tentang bagaimana membuat bioetanol dari limbah buah secara lebih menarik maka lahirlah ide untuk membuat permainan dengan konsep pengembangan multimedia yang merupakan sebuah konsep dan teknologi dari unsur-unsur gambar, suara, animasi serta video yang disatukan di dalam komputer untuk disimpan, diproses, dan disajikan guna membentuk interaksi yang sangat inovatif antara komputer dengan pengguna.

Pengembangan sistem permainan menggunakan tahap pengembangan multimedia yang terdiri dari menentukan konsep, membuat perancangan, pengumpulan bahan materi yang diperlukan, pembuatan, pengujian dan pendistribusian permainan kepada pengguna. Perangkat lunak aplikasi yang digunakan dalam pembuatan permainan ini adalah Adobe Flash CS3 dengan bahasa pemrograman action script 2.0. Adobe Flash CS3 adalah salah satu perangkat lunak yang dapat digunakan untuk membuat animasi yang menarik. Dengan Adobe Flash CS3 aplikasi permainan yang dibuat dapat dilengkapi dengan beberapa macam animasi, audio, interaktif animasi, dan lain-lain. Kebutuhan sistem yang diperlukan untuk menjalankan permainan ini adalah sistem operasi Windows, dan Flash Player yang sudah terpasang pada laptop/komputer pengguna.

Permainan membuat bioetanol ini ditujukan untuk semua kalangan dan usia, namun lebih dikhususkan untuk kalangan pelajar SMP dikarenakan pada masa jenjang pendidikan ini sesuai dengan kurikulum mata pelajaran ilmu pengetahuan alam telah diajarkan tentang unsur, senyawa, larutan asam basa yang diperlukan sebagai dasar awal untuk memahami istilah-istilah dalam pembuatan bioetanol. Hasil pengujian permainan menunjukkan bahwa permainan ini dapat berjalan dengan baik pada sistem operasi Windows 7. Tombol-tombol dan fungsi-fungsi pada permainan juga dapat berfungsi dengan baik dan sesuai dengan fungsionalitasnya masing-masing pengujian ini dilakukan dengan menggunakan metode black-box. Berdasarkan pengujian yang dilakukan oleh pengguna yaitu 30 siswa SMP, permainan “Membuat Bioetanol Dari Limbah Buah” ini membantu dalam mengenalkan tahap-tahap membuat bioetanol dari limbah buah, serta tampilan permainannya bagus. Hal ini terlihat pada semua aspek penilaian yang telah dihitung menggunakan skala Likert. Permainan ini dapat digunakan sebagai media yang dapat memberikan pengetahuan tentang tahap-tahap dalam membuat bioetanol dari limbah buah.
\end{abstract}

Kata kunci : Adobe Flash CS3, Bioetanol, Permainan, Multimedia, Black-box, Likert, SMP, Windows.

\section{Pendahuluan}

Bahan bakar minyak yang banyak digunakan sekarang ini bersumber dari hasil pembusukan fosil yang terperangkap dibawah lapisan permukan bumi selama berjuta-juta tahun lamanya. Bahan bakar minyak ini termasuk kedalam jenis sumber daya alam yang sulit untuk diperbaharui karena prosesnya membutuhkan waktu yang sangat lama. Namun apabila dilihat dari segi pemakaiannya, penggunaan bahan bakar ini tergolong sangat tinggi terutama pada sektor transportasi. Oleh karena itu dikhawatirkan pada masa mendatang dapat terjadi kelangkaan akan bahan bakar minyak. Diperlukan sebuah bahan bakar alternatif yang bisa mengantikan bahan bakar fosil, salah satunya adalah dengan bahan bakar nabati yaitu bioetanol berbahan dasar ekstrak limbah buah.
Dukungan teknologi yang berkembang saat ini, memberikan banyak kemudahan bagi manusia, seperti kemudahan komunikasi, kemudahan transportasi, dan kemudahan di bidang lainnya. Dengan kemajuan teknologi yang semakin pesat ini, semakin banyak pula sarana belajar dan penyebaran informasi dengan bentuk yang lebih menarik dan interaktif seperti dengan menggunakan permainan, permainan berbasis komputer selain dapat dijadikan sebagai media belajar, juga dapat sebagai media hiburan. Selain berpengaruh pada permainan perkembangan teknologi juga melahirkan sebuah perkembangan pada teknologi multimedia. Multimedia merupakan sebuah konsep dan teknologi dari unsur-unsur gambar, suara, animasi serta video yang disatukan di dalam komputer untuk disimpan, diproses, dan disajikan guna membentuk interaksi yang sangat inovatif antara komputer dengan pengguna. 
Lahirlah sebuah gagasan tentang pengenalan tentang tahap-tahap pembuatan bioetanol yang dibuat dengan mengimplementasikan teknologi dari multimedia kedalam sebuah permainan. Permainan yang akan dibangun dibuat dengan menggunakan software aplikasi Adobe Flash CS3. Adobe Flash CS3 adalah salah satu software yang dapat digunakan untuk membuat animasi yang menarik. Dengan Adobe Flash CS3 aplikasi permainan yang dibuat dapat dilengkapi dengan beberapa macam animasi, audio, interaktif animasi, dan lain-lain. Oleh karena itu muncullah ide untuk membuat sebuah permainan membuat bioetanol dari limbah dengan menggunakan Adobe Flash CS3 dengan mengimplementasikan pengembangan konsep dari multimedia. Konsep pengembangan dengan multimedia dalam permainan dibuat untuk membuat suasana yang lebih menarik dan interaktif.

Permainan ini dapat dimainkan oleh semua kalangan dan jenis kelamin, namun lebih dikhususkan untuk kalangan pelajar Sekolah Menengah Pertama, dimana pada masa pendidikan sekolah menengah pertama, hal ini karena pada masa tersebut telah diberikan pelajaran ilmu pengetahuan alam yang pada salah satu bagiannya memberikan penjelasan tentang unsur, senyawa, larutan asam dan basa, sehingga istilahistilah yang ada pada permainan sudah dapat dimengerti. Selain itu permainan ini diberikan sejak awal agar generasi muda mampu mengenal tahap-tahap dasar pembuatan bahan bakar alternatif bioetanol yang terbuat dari ekstrak limbah buah.

\section{Dasar Teori}

\subsection{Definisi Permainan}

Permainan yaitu suatu cara belajar yang digunakan dalam menganalisis interaksi antara sejumlah pemain maupun perorangan yang menunjukkan strategistrategi yang rasional. Permainan juga merujuk pada kelincahan intelektual, dimana terdapat target-target yang ingin dicapai pemainnya.

Permainan diklasifikasikan menjadi lima kelompok yakni permainan papan, permainan kartu, permainan atletik, permainan anak-anak, dan permainan komputer. Permainan komputer merupakan suatu bentuk seni karena menghadirkan pengalaman berkhayal bagi pemainnya dan menstimulasi emosi pemainnya.

\subsection{Definisi Multimedia}

Multimedia adalah pemanfaatan komputer untuk membuat dan menggabungkan beberapa media seperti teks, grafik, suara, dan gambar gerak (animasi dan video) dengan menggabungkan tautan dan perangkat yang memungkinkan pemakai melakukan navigasi, berinteraksi, dan berkomunikasi. Komponen-komponen multimedia diantaranya adalah:

1. Teks

Teks dapat berupa kata atau narasi dalam multimedia yang menyajikan bahasa. Kebutuhan teks tergantung pada kegunaan aplikasi multimedia.

2. Grafik (Image)
Grafik menjadi nilai dan unsur tambah suatu penyajian data. Gambar digunakan dalam presentasi multimedia untuk menarik perhatian dan dapat mengurangi kebosanan, apabila dibandingkan dengan teks.

3. Suara (Audio)

Penyampaian sebuah informasi yang sering disertai desain grafis dan teks yang menarik, akan terasa hampa dan membosankan apabila tidak disertai dengan suara di dalamnya. Diperlukan narasi atau suara yang menyertai dan menjelaskan informasi yang disampaikan agar lebih mudah dipahami.

4. Video

Video akan membuat aplikasi multimedia lebih hidup. Namun kendala yang dihadapi dalam memanfaatkan media ini adalah ukuran berkas yang terlalu besar.

5. Animasi

Multimedia animasi merupakan penggunaan komputer untuk menciptakan gerak.

\subsection{Adobe Flash CS3}

Adobe Flash CS3 Professional merupakan sebuah program aplikasi standar authoring tool professional yang digunakan untuk membuat animasi vektor dan bitmap yang dimanfaatkan untuk keperluan pembangunan situs web yang interaktif dan dinamis. Berikut ini beberapa bagian / komponen pada Adobe Flash CS3 Professional.

1. Title Bar adalah sebuah baris informasi yang terletak di sudut kiri paling atas aplikasi yang menerangkan judul movie yang sedang dikerjakan.

2. Menu Bar adalah kumpulan menu yang terdiri atas daftar menu-menu yang digolongkan dalam satu kategori. Misalnya menu file terdiri atas perintah New, Open, Save, Import, Eksport dan lain-lain.

3. Tool Box adalah kumpulan perangkat yang sering digunakan untuk melakukan seleksi, menggambar, memberi warna objek, memodifikasi objek, dan mengatur besar-kecil tampilan stage.

4. Timeline adalah sebuah jendela panel yang digunakan untuk mengelompokkan dan mengatur isi sebuah movie. Pengaturan tersebut meliputi menentukan masa tayang objek, pengaturan layer dan lain-lain. Di dalam fitur ini terdapat Layer, Frame, Keyframe, Layer Guide dan Stage.

Animasi yang dapat dilakukan Flash diantaranya adalah:

1. Frame-by-frame animation, menggambar satu per satu gambar pada bingkai dan setelah semuanya selesai baru kemudian dianimasikan.

2. Tweened animation, Ada dua jenis yaitu Motion tweening dan Shape tweening.

\subsection{Tahap-Tahap Pembuatan Bioetanol Ekstrak Limbah Buah. \\ Berikut ini tahapan-tahapan dalam membuat bioetanol ekstrak limbah buah yang dilakukan pada penelitian sebelumnya bersama Teknik Lingkungan Undip pada tahun 2012.}


1. Tahap Pengolahan Awal

Pada tahap ini dilakukan penghalusan dan penyaringan sampah buah. Penghalusan sampah dengan perbandingan jumlah sampah dan air yaitu 75\%: $25 \%$. Lalu sampah dimasukkan ke blender dan dicampurkan dengan air kemudian dihaluskan. Setelah sampah dihaluskan, sampah disaring dengan menggunakan saringan makanan/kain untuk mendapatkan ekstrak buah.

2. Tahap Hidrolisis

Hidrolisis dimulai dengan memasukkan larutan $\mathrm{HCl} 7 \%$ ke dalam cairan sampah yang berfungsi untuk meningkatkan kereaktifan air. $\mathrm{HCl}$ dimasukkan dalam sampel hingga $\mathrm{pH}$ 1-2. Kemudian dipanaskan dengan menggunakan panci hingga suhu mencapai $100^{\circ} \mathrm{C}$ (mendidih). Filtrat yang telah dipanaskan kemudian didinginkan dan ditambahkan $\mathrm{NaOH}$ hingga $\mathrm{pH}$ mencapai 4-5.

\section{Tahap Fermentasi}

Ragi tape sebanyak 9 gram dimasukkan pada botol dengan volume $400 \mathrm{ml}$ kemudian diaduk-aduk. Setelah itu botol ditutup dengan plastik atau karet penutup dan dilanjutkan fermentasi selama 9 hari (lama fermentasi menyesuaikan kondisi bioetanol apabila bioetanol telah dalam kondisi yang diinginkan maka proses fermentasi dapat dihentikan). Fermentasi dilakukan pada suhu $28^{\circ} \mathrm{C}$ secara anaerob.

4. Tahap Distilasi (Penyulingan)

Tahap selanjutnya yang dilakukan adalah distilasi. Distilasi dilakukan untuk memisahkan bioetanol dan air. Titik didih etanol murni adalah $78^{\circ} \mathrm{C}$ sedangkan air adalah $100^{\circ} \mathrm{C}$ (kondisi standar). Dengan memanaskan larutan pada suhu rentang $78-100^{\circ} \mathrm{C}$ akan mengakibatkan sebagian besar etanol menguap, dan melalui unit kondensasi akan bisa dihasilkan bioetanol.

\section{Perancangan Sistem Permainan}

\subsection{Tahap-tahap dalam Pengembangan Sistem}

Multimedia

Dalam mengembangkan sebuah permainan multimedia yang baik perlu dilakukan sebuah perancangan yang matang agar hasilnya dapat beroperasi dengan baik dan juga sesuai dengan yang diharapkan. Pengembangan permainan ini, menggunakan metode pengembangan multimedia yang terdiri dari 6 tahap yaitu konsep, desain (design), pengumpulan bahan (material collecting), pembuatan (assembly), pengujian (testing), dan distribusi

\section{$3.2 \quad$ Konsep}

Konsep dari perancangan permainan adalah sebagai berikut ini:

Tabel 1. Tabel deskripsi konsep permainan

\begin{tabular}{|l|c|l|}
\hline Judul & $:$ & $\begin{array}{l}\text { Permainan } \\
\text { Bioetanol Dari Limbah Buah }\end{array}$ \\
\hline Pengguna & $:$ & Pelajar SMP (dikhususkan) \\
\hline Jenis Permainan & $:$ & Edugames \\
\hline
\end{tabular}

\begin{tabular}{|l|c|l|}
\hline Durasi & $:$ & $\begin{array}{l}\text { 3 menit (level 1 - 2), 2 menit } \\
\text { (level 3) }\end{array}$ \\
\hline Image & $:$ & $\begin{array}{l}\text { Menggunakan gambar yang } \\
\text { digambar sendiri dan } \\
\text { disempurnakan dengan } \\
\text { Adobe Photoshop. }\end{array}$ \\
\hline Audio & $:$ & $\begin{array}{l}\text { Menggunakan efek suara dan } \\
\text { backsound }\end{array}$ \\
\hline Video & $:$ & Tidak menggunakan \\
\hline Animasi & $:$ & $\begin{array}{l}\text { Animasi perubahan objek ke } \\
\text { objek lain pada meja kerja. }\end{array}$ \\
\hline Interaktif & $:$ & $\begin{array}{l}\text { Drag dan drop objek ke } \\
\text { objek lain oleh pengguna } \\
\text { permainan. }\end{array}$ \\
\hline Timer & $:$ & $\begin{array}{l}\text { Menggunakan timer untuk } \\
\text { melatih kecepatan pengguna } \\
\text { pada setiap level. }\end{array}$ \\
\hline Nilai & $:$ & Tidak diperlukan \\
\hline $\begin{array}{l}\text { Kesempatan } \\
\text { Bermain (Nyawa) }\end{array}$ & $:$ & \begin{tabular}{l} 
3 kali kesempatan \\
\hline
\end{tabular}
\end{tabular}

\subsection{Perancangan/Desain Storyboard}

Dalam pembuatan sistem ini dibutuhkan beberapa storyboard. Storyboard berfungsi sebagai dasar untuk mempermudah pembuatan animasi objek baik dalam web maupun dalam flash.

\section{STORYBOARD}

a. Storyboard scene 1

Berikut ini merupakan storyboard scene 1 yang digambarkan pada Gambar 1, storyboard dibuat berdasarkan konsep pembuatan storyboard menurut Luther.

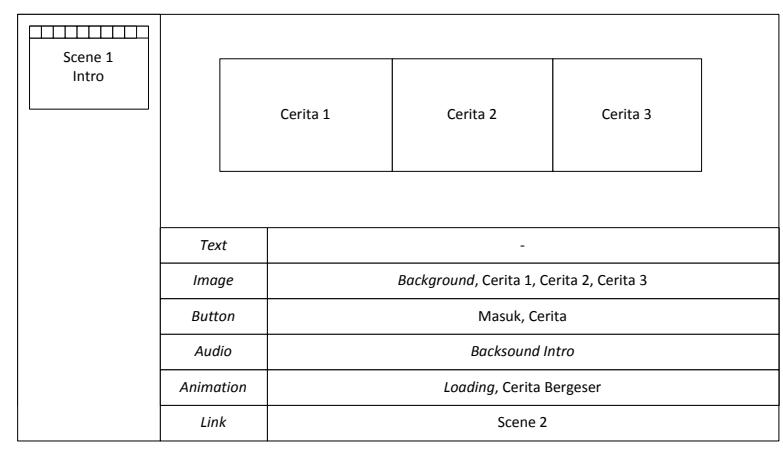

Gambar 1. Storyboard scene 1

Rancangan storyboard yang pertama merupakan gambaran tampilan yang akan dibuat pada scene 1. Pada scene ini berisi intro (permulaan) permainan yang menceritakan latar belakang dari permainan yang dijelaskan dalam bentuk gambar. Cerita dibuat kedalam 3 buah gambar dimana perpindahan dari satu gambar ke gambar yang lain dengan cara meng-klik gambar, maka gambar akan bergeser dari gambar satu menuju gambar selanjutnya. Pada scene 1 terdapat beberapa objek multimedia yaitu image (gambar) yang berupa gambar background tampilan, gambar cerita 1, gambar cerita 2, 
dan gambar cerita 3. Suara (audio) yang terdapat pada scene 1 adalah backsound musik untuk intro (permulaan) dari permainan. Animasi yang terdapat pada scene 1 adalah cerita yang dapat bergeser. Pada scene 1 terdapat link yang akan mengarah menuju scene 2.

\section{b. Storyboard scene 2}

Gambar 2 merupakan storyboard scene 2, storyboard dibuat berdasarkan konsep pembuatan storyboard menurut Luther.

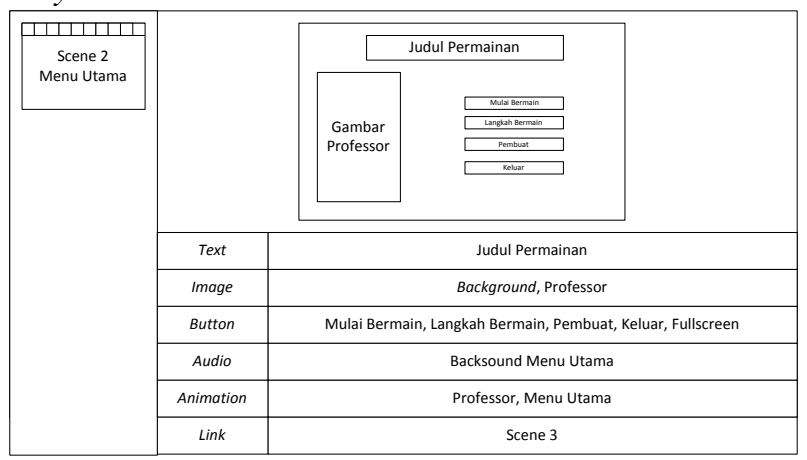

Gambar 2. Storyboard scene 2

Rancangan tampilan yang kedua merupakan gambaran tampilan yang akan dibuat pada scene 2, yaitu tampilan menu utama permainan. Pada scene ini berisi menu-menu utama yang terdapat pada permainan. Menumenu tersebut terdiri dari menu mulai bermain, menu petunjuk bermain, menu pembuat dan menu keluar dari permainan. Pada scene 2 terdapat beberapa objek multimedia seperti teks yaitu berupa teks judul permainan. Image (gambar) yang berupa gambar background tampilan, dan gambar professor. Button (tombol) terdiri dari tombol mulai bermain, tombol petunjuk bermain, tombol pembuat, tombol keluar dan tombol fullscreen/normalscreen. Audio (suara) yang terdapat pada scene 2 adalah backsound musik untuk menu utama. Animasi pada scene 2 adalah munculnya gambar professor diikuti dengan menu-menu yang ada. Pada scene 2 terdapat link berupa tombol yang akan mengarah menuju scene 3 .

\section{c. Storyboard scene 3}

Gambar 3 merupakan storyboard scene 3, storyboard dibuat berdasarkan konsep pembuatan storyboard menurut Luther.

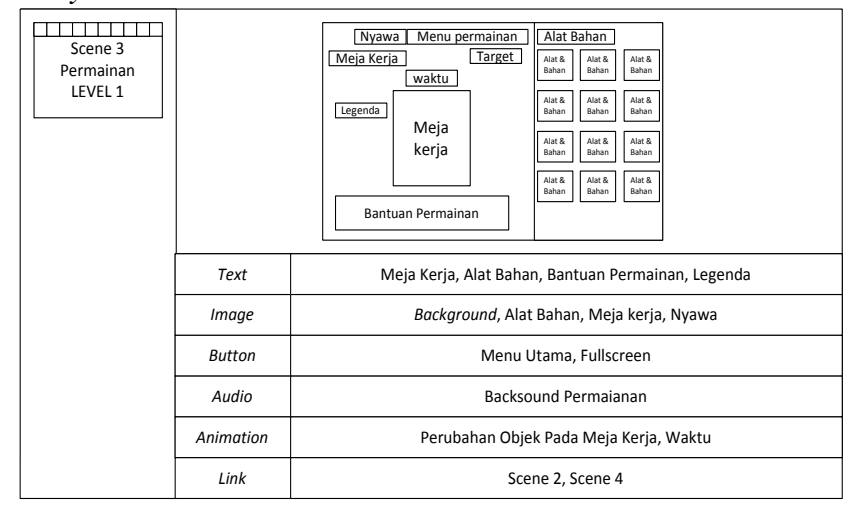

Gambar 3. Storyboard scene 3
Scene 3 merupakan tampilan permainan level 1 dimana pengguna harus dapat menyelesaikan target untuk membuat 2 botol bioetanol dengan waktu 3 menit. Pada halaman utama permainan ini terbagi menjadi dua bagian yaitu bagian alat bahan dan bagian meja kerja. Pada bagian alat bahan terdapat objek-objek alat dan bahan yang akan digunakan pada permainan. Sedangkan pada bagian meja kerja merupakan tempat diletakannya alat dan bahan yang akan diinteraksikan.

Selain itu terdapat keterangan tentang petunjuk/langkah-langkah permainan yang diberikan oleh professor, legenda/keterangan dari objek yang ada pada meja kerja, sisa waktu bermain, nyawa (kesempatan bermain) dan tombol menu permainan yang terdiri dari tombol ke menu utama dan tombol untuk fullscreen/normalscreen. Pada scene 3 terdapat beberapa objek multimedia yaitu image (gambar) yang berupa gambar background tampilan, gambar objek alat dan bahan, gambar nyawa (kesempatan bermain). Button (tombol) yang ada pada scene 3 yaitu tombol menuju kembali ke menu utama dan tombol fullscreen/normalscreen. Audio (suara) yang terdapat pada scene 3 adalah backsound untuk permainan utama, dan animasi pada scene 3 adalah perubahan objek benda pada meja kerja. Pada scene 3 terdapat link yang akan mengarah menuju scene 3 dan scene 4 (permainan level 2)

\section{d. Storyboard scene 4 dan scene 5}

Gambar 4 dan Gambar 5 merupakan storyboard scene 4 dan scene 5, storyboard dibuat berdasarkan konsep pembuatan storyboard menurut Luther.

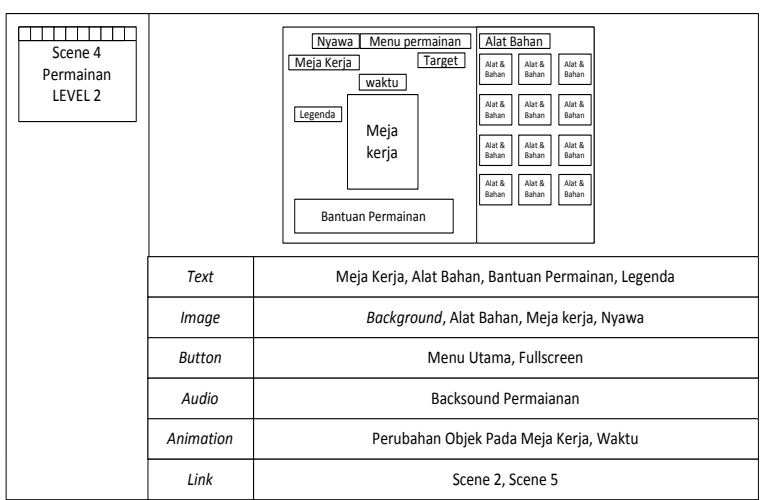

Gambar 4. Storyboard scene 4

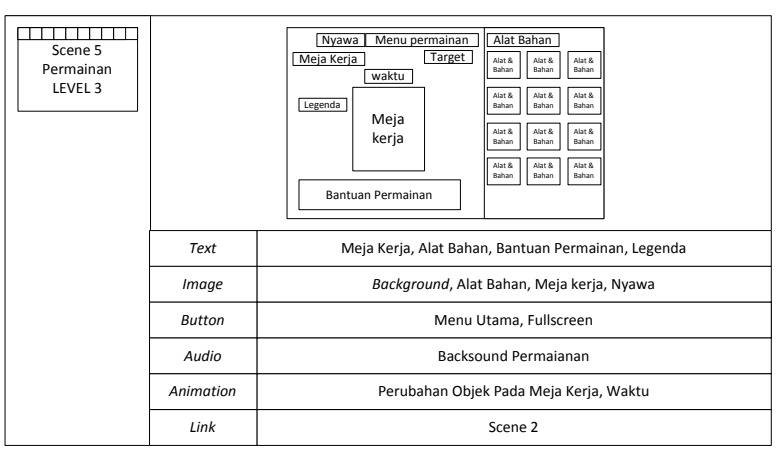

Gambar 5. Storyboard scene 5 
Storyboard scene 4 dan scene 5 sama dengan perancangan storyboard pada scene 3. Perbedaannya hanya pada target permainan yang harus diselesaikan. Scene 4 yang merupakan level kedua permainan yang mempunyai target membuat 4 botol bioetanol dalam batas waktu 3 menit. Sedangkan pada scene 5 mempunyai target membuat 4 botol bioetanol namun hanya dengan waktu 2 menit.

\subsection{Pengumpulan Bahan}

Material Collecting merupakan tahap mengumpulkan bahan seperti gambar, animasi, suara, pembuatan citra grafik, foto, dan lain-lain yang diperlukan untuk tahap berikutnya dalam proses pembuatan permainan.

\section{Pembuatan dan Pengujian Sistem}

\subsection{Pembuatan Scene 1}

Proses pembuatan pertama dimulai dengan pembuatan scene 1, dimana scene 1 berisi cerita latar belakang permainan. Pertama masukan bahan yang di butuhkan dalam scene 1 yaitu gambar cerita 1 , cerita 2 dan cerita 3. Gambar-gambar cerita akan disusun sejajar dan diberi animasi bergeser. Kemudian membuat tombol berbentuk transparan yang digunakan untuk mengendalikan animasi pergeseran gambar cerita tersebut, sehingga apabila gambar tersebut di-klik maka akan menuju gambar cerita selanjutnya.

Pada proses pembuatan scene 1 pada Adobe Flash CS3 terdapat 7 layer yang terdiri dari layer btnfs (button fullscreen), layer keterangan, layer loading, layer 20, layer background, layer tombol next dan layer cerita.

Gambar 6 menunjukan penyusunan rangkaian cerita 1, cerita 2 dan cerita 3 pada Adobe Flash CS3.

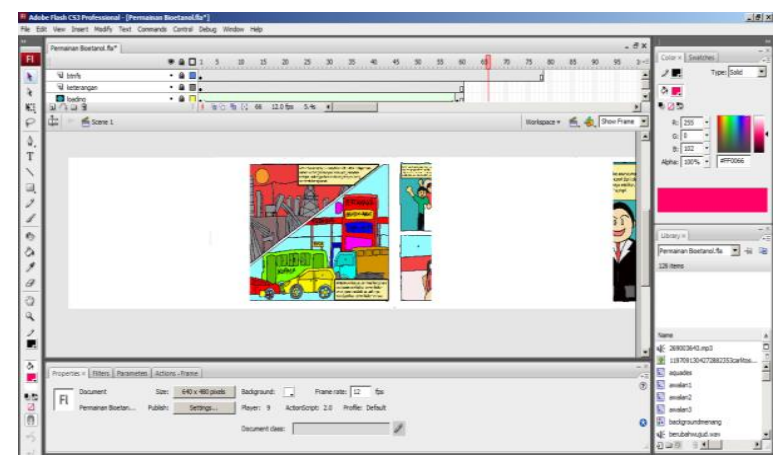

Gambar 6. Pembuatan cerita permainan pada Adobe Flash CS3

Berikut adalah hasil keluaran yang dihasilkan dari pembuatan scene 1, dimulai dengan gambar cerita pertama yang menceritakan habisnya bahan bakar minyak serta antrian para pengguna bahan bakar pada saat akan membeli bahan bakar di pom bensin yang akan ditunjukkan pada Gambar 7.

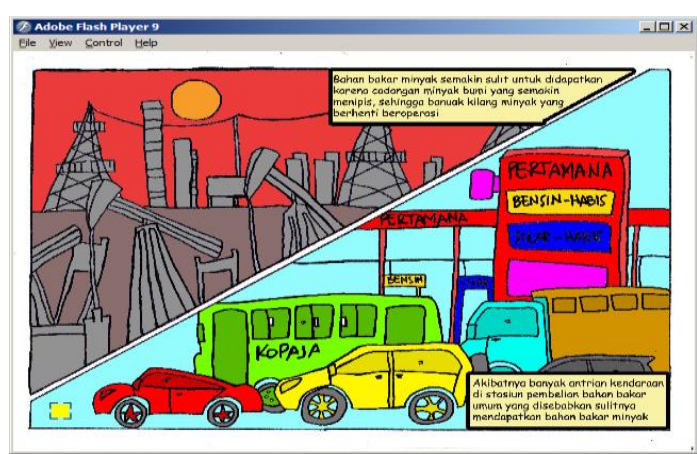

Gambar 7. Tampilan cerita 1 pada permainan

Gambar 8 menunjukan gambar cerita kedua yaitu gambar yang menceritakan unjuk rasa yang dilakukan oleh masyarakat dan pembahasan yang dilakukan oleh pemerintah dalam rangka menghadapi situasi yang sedang terjadi.

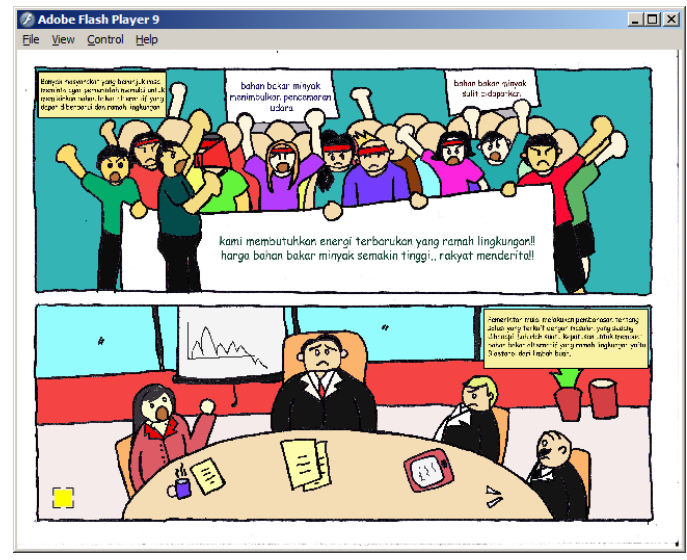

Gambar 8. Tampilan cerita 2 pada permainan

Gambar terakhir adalah gambar ketiga yang menceritakan tokoh yang memberi instruksi kepada pengguna permainan untuk membantu dalam pembuatan bioetanol. Tampilan cerita ketiga tampak pada Gambar 9.

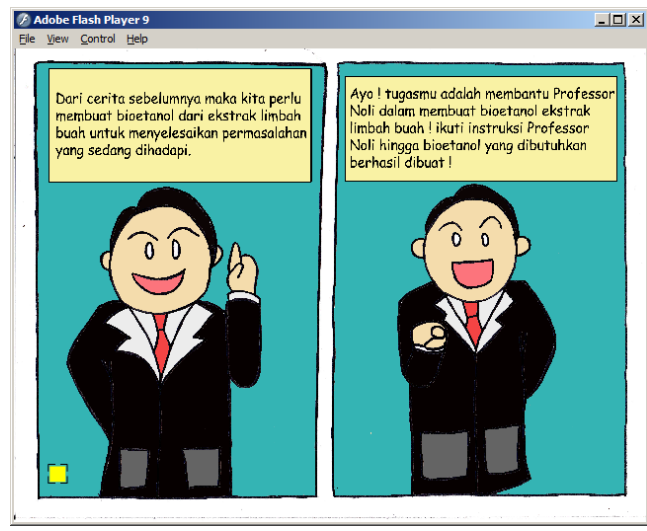

Gambar 9. Tampilan cerita 3 pada permainan

\subsection{Pembuatan Scene 2}

Setelah scene 1 telah berhasil dibuat, langkah selanjutnya adalah membuat scene 2 , proses pembuatan telah disesuaikan dengan rancangan yang sudah dibuat sebelumnya. Scene 2 menampilkan tombol menu utama 
pada permainan, seperti tombol menu mulai bermain, tombol menu petunjuk bermain, tombol menu pembuat, dan tombol menu keluar. Tombol menu mulai bermain berfungsi untuk memulai permainan yang ada pada scene 3 , sehingga fungsi sebenarnya dari tombol menu mulai bermain adalah untuk berpindah scene, dari scene 2 menuju scene 3. Tombol menu petunjuk bermain, berfungsi untuk menampilkan informasi tentang petunjuk permainan, halaman petunjuk permainan terdapat pada scene 2 sehingga perintah pada tombol tersebut adalah hanya untuk berpindah frame. Tombol menu pembuat sama dengan tombol menu petunjuk bermain, yang membedakan adalah apa yang ditampilkan, tombol menu pembuat akan menampilkan informasi pembuat permainan. Tombol menu keluar, sesuai dengan namanya tombol ini berfungsi untuk keluar dari permainan. Tombol fullscreen/normalscreen berfungsi untuk mengubah tampilan permainan menjadi fullscreen atau normalscreen. Kemudian tombol-tombol menu tersebut diberi animasi kemunculan agar tampak menarik, serta tidak lupa dengan menambahkan animasi professor dan judul permainan.

Pada pembuatan scene 2 ini terdapat 14 layer yang terdiri dari layer pembuat, layer petunjuk bermain, layer btnfs, layer bgsound, layer suara, layer btnkeluar, layer btnpembuat, layer btnpetunjukbermain, layer btnmulaibermain, layer professor, layer namaprofessor, layer judul, layer latarlayar, dan yang terakhir adalah layer background.

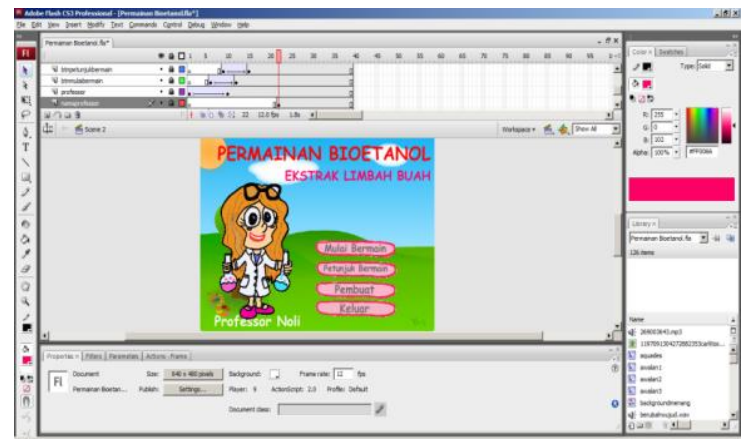

Gambar 10. Pembuatan tampilan scene 2 permainan pada Adobe Flash CS3

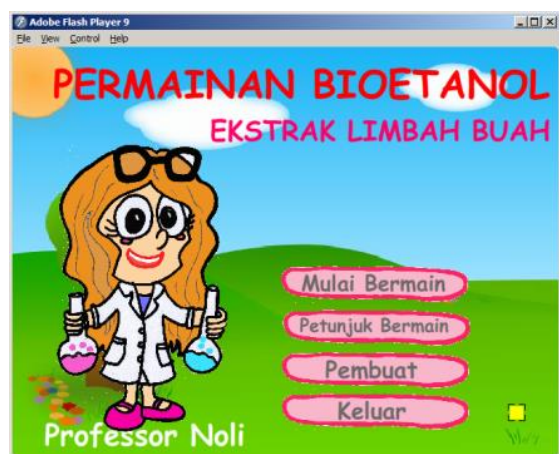

Gambar 11. Tampilan scene 2/halaman utama permainan

\subsection{Pembuatan Scene 3}

Pada scene 3 berisi inti dari permainana yang akan dimainkan, scene 3 merupakan perancangan level 1 permainan. Pembuatan scene 3 dimulai dengan membagi bagian gambar latar belakang menjadi dua, yang bertujuan membagi wilayah kerja yaitu bagian alat dan bahan dan bagian meja kerja. Pada bagian alat dan bahan diisi objek-objek alat dan bahan, dan untuk meja kerja berisi objek meja kerja yang akan bereaksi terhadap objek alat dan bahan yang dipilih, objek petunjuk permainan yang kan memberi petunjuk langkah-langkah yang harus dilakukan, objek waktu bermain, objek target misi jumlah botol bioetanol yang harus dibuat, objek kesempatan bermain, dan objek menu permainan, yang meliputi tombol menu kembali ke menu utama dan tombol untuk fullscreen/normalscreen. Sehingga kita perlu membuat semua objek-objek tersebut terlebih dahulu. Setelah selesai membuat semua objek dengan bahan-bahan yang telah dikumpulkan pada tahap sebelumnya. Pada scene 3 terdapat 6 layer yaitu layer Animasi Mulai, layer backsound, layer suara efek, layer objek, layer Fullscreen Button, dan layer background tampilan. Gambar 12 merupakan pembuatan tampilan permainan pada scene 3 .

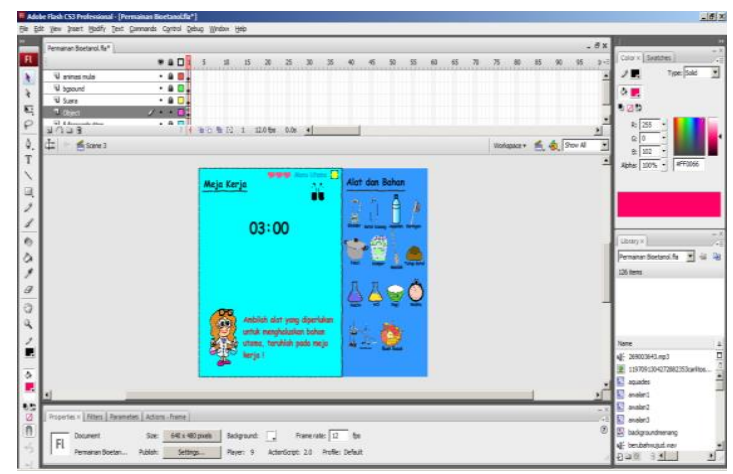

Gambar 12. Pembuatan halaman permainan level 1/scene 3 pada Adobe Flash CS3

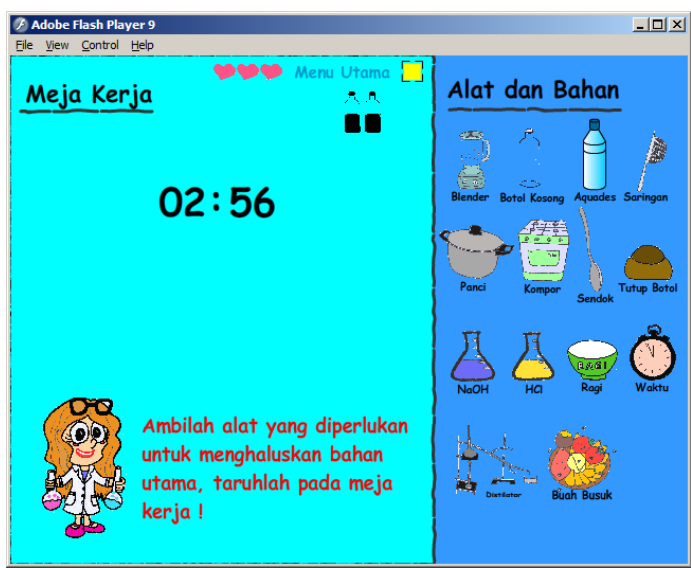

Gambar 13. Tampilan permainan level 1

\subsection{Pembuatan Scene 4 dan Scene 5}

Pembuatan pada scene 4 dan scene 5 sama dengan pembuatan pada scene 3 , yang membedakan antara scene 3, scene 4 dan scene 5 adalah target jumlah pembuatan bioetanol pada setiap levelnya. Pada scene 4 target permainan menjadi lebih banyak dibandingkan pada scene 3 (level 1) yaitu dari 2 botol pada scene 3 
menjadi 4 botol pada scene 4, sedangkan pada scene 5 jumlah target botol bioetanol yang harus diselesaikan sama dengan scene 4 yaitu 4 botol, namun waktu bermain diubah menjadi lebih cepat hanya 2 menit.

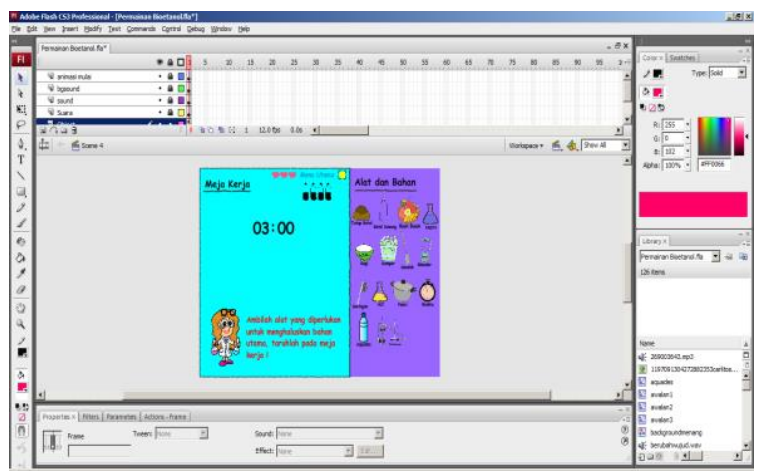

Gambar 14. Pembuatan halaman permainan level 2 pada Adobe Flash CS3

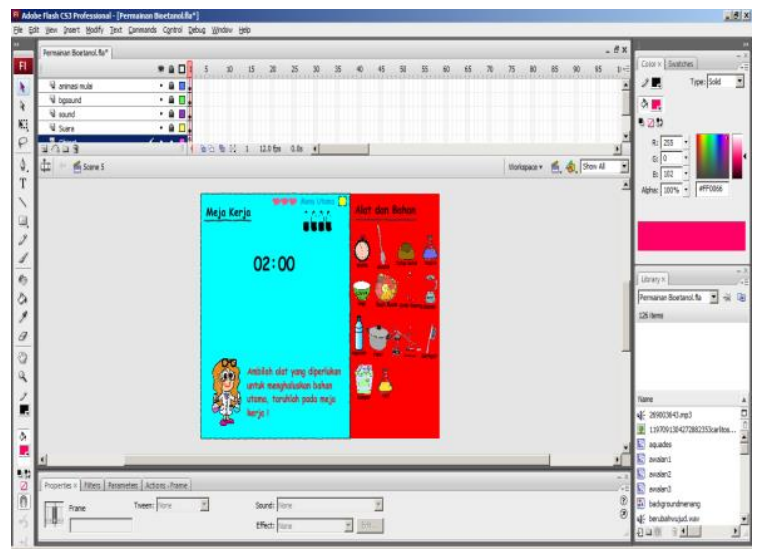

Gambar 15. Pembuatan halaman permainan level 3 pada Adobe Flash CS3

\subsection{PENGUJiAn PERMAINAN}

Pengujian permainan membuat bioetanol dari limbah buah dilakukan dengan menggunakan metode black-box, dengan kata lain pengujian yang menekankan pada fungsionalitas dari permainan. Tahap ini berisi serangkaian pengujian fungsi dan tombol pada permainan. Tingkat keberhasilan pengujian, diukur dari terpenuhinya spesifikasi kebutuhan dan skenario permainan. Pengujian permainan dijalankan pada sistem operasi Windows 7 yang telah terpasang Adobe Flash Player. Cara pengujiannya hanya dilakukan dengan menjalankan permainan, kemudian diamati apakah hasilnya sesuai dengan spesifikasi kebutuhan. Hasil dari pengujian fungsi pada permainan ini, dapat dilihat pada Tabel 2.

Tabel 2. Tabel Pengujian Fungsi pada Permainan

\begin{tabular}{|c|l|c|}
\hline No. & \multicolumn{1}{|c|}{ Fungsi } & Hasil Uji \\
\hline 1. & $\begin{array}{l}\text { Menampilkan tampilan loading } \\
\text { pada awal permainan }\end{array}$ & Berhasil \\
\hline 2. & Pemilihan menu Simulasi & Berhasil \\
\hline 3. & Pemilihan menu Materi & Berhasil \\
\hline 4. & Pemilihan menu Info & Berhasil \\
\hline
\end{tabular}

\begin{tabular}{|c|l|c|}
\hline 5. & Pemilihan menu Kredit & Berhasil \\
\hline 6. & $\begin{array}{l}\text { Pemilihan tombol Keluar pada } \\
\text { aplikasi dekstop }\end{array}$ & Berhasil \\
\hline 7. & $\begin{array}{l}\text { Menjalankan simulasi pada tahap } \\
\text { pengolahan awal }\end{array}$ & Berhasil \\
\hline 8. & $\begin{array}{l}\text { Menjalankan simulasi pada tahap } \\
\text { hidrolisis }\end{array}$ & Berhasil \\
\hline 9. & $\begin{array}{l}\text { Menjalankan simulasi pada tahap } \\
\text { fermentasi }\end{array}$ & Berhasil \\
\hline 10. & $\begin{array}{l}\text { Menjalankan simulasi pada tahap } \\
\text { distilasi }\end{array}$ & Berhasil \\
\hline 11. & Permainan Berhasil & Berhasil \\
\hline 12. & Permainan Gagal & Berhasil \\
\hline
\end{tabular}

Dalam permainan ini terdapat 7 tombol : tombol Masuk, Pembuat, Cara Bermain, Mulai Bermain, fullsreen/normalscreen, Menu Utama, serta Keluar. Tabel 4.2 menunjukkan hasil pengujiannya.

Tabel 3. Tabel pengujian tombol pada permainan

\begin{tabular}{|c|c|c|c|}
\hline No. & $\begin{array}{l}\text { Parameter } \\
\text { Pengujian }\end{array}$ & Keterangan & $\begin{array}{c}\text { Hasil } \\
\text { Uji }\end{array}$ \\
\hline 1. & Tombol Masuk & $\begin{array}{c}\text { Ketika tombol } \\
\text { ditekan, maka layer } \\
\text { akan menjalankan } \\
\text { frame berikutnya } \\
\text { yaitu tampilan menu } \\
\text { permainan. }\end{array}$ & Benar \\
\hline 2. & $\begin{array}{c}\text { Tombol } \\
\text { Pembuat }\end{array}$ & $\begin{array}{c}\text { Ketika tombol } \\
\text { ditekan, permainan } \\
\text { akan menampilkan } \\
\text { nama pembuat } \\
\text { permainan. }\end{array}$ & Benar \\
\hline 3. & $\begin{array}{l}\text { Tombol } \\
\text { Petunjuk } \\
\text { Bermain }\end{array}$ & $\begin{array}{l}\text { Ketika tombol } \\
\text { ditekan, maka } \\
\text { permainan akan } \\
\text { menampilkan } \\
\text { informasi tentang } \\
\text { petunjuk bermain }\end{array}$ & Benar \\
\hline 4. & $\begin{array}{l}\text { Tombol Mulai } \\
\text { Bermain }\end{array}$ & $\begin{array}{c}\text { Ketika tombol } \\
\text { ditekan, maka } \\
\text { permainan akan } \\
\text { masuk ke halaman } \\
\text { simulasi pembuatan } \\
\text { bioetanol. }\end{array}$ & Benar \\
\hline 5. & $\begin{array}{c}\text { Tombol } \\
\text { fullscreen dan } \\
\text { normalscreen }\end{array}$ & $\begin{array}{c}\text { Ketika tombol } \\
\text { ditekan, maka akan } \\
\text { memperbesar } \\
\text { (fullscreen) dan } \\
\text { apabila ditekan } \\
\text { kembali akan } \\
\text { mengembalikan } \\
\text { menjadi ukuran } \\
\text { awal } \\
\text { (normalscreen). }\end{array}$ & Benar \\
\hline 6. & $\begin{array}{c}\text { Tombol Menu } \\
\text { Utama }\end{array}$ & $\begin{array}{c}\text { Ketika tombol } \\
\text { ditekan, maka akan } \\
\text { kembali ke halaman } \\
\text { menu permainan. }\end{array}$ & Benar \\
\hline & & & \\
\hline
\end{tabular}




\begin{tabular}{|c|c|c|c|}
\hline 7. & Tombol Keluar & $\begin{array}{c}\text { Ketika tombol } \\
\text { ditekan, maka } \\
\text { permainan dalam } \\
\text { bentuk dekstop akan } \\
\text { keluar/tertutup. }\end{array}$ & Benar \\
\hline
\end{tabular}

Berdasarkan hasil persentase dan dari hasil perhitungan validasi dan reliabilitas yang telah dihitung menggunakan SPSS maka diperoleh pengujian terhadap siswa sekolah menengah pertama sebanyak 30 responden yaitu, sebesar $76.7 \%$ siswa menilai bagus pada tampilan permainan ini, dan $76 \%$ siswa menyatakan bahwa permainan ini membantu dalam mengenalkan tahapan membuat bioetanol secara lebih mudah.

Permainan "Membuat Bioetanol Dari Limbah Buah" ini sudah dijadikan berkas *.exe, sehingga dapat dijalankan pada semua notebook atau komputer berbasis windows. Ukuran dari permainan ini tidak terlalu besar, yaitu 8,5 MB, sehingga tidak akan terlalu menyita ruang pada harddisk.

\section{KESIMPULAN}

Dari hasil pengujian dan analisis permainan "membuat bioetanol dari limbah buah" dapat disimpulkan hal-hal sebagai berikut.

1. Permainan ini dibuat menggunakan Adobe Flash CS3 dan dapat berjalan baik pada sistem operasi Windows 7, serta hasil dari pengujian permainan dengan menggunakan metode black-box mendapatkan hasil bahwa tombol-tombol dan fungsi-fungsi yang terdapat pada permainan dapat berfungsi dengan baik dan sesuai dengan fungsionalitasnya masing-masing.

2. Permainan ini berisi tahap pembuatan bioetanol dengan menggunakan bahan dasar limbah buah yang dikemas ke dalam sebuah permainan.

4. Berdasarkan pengujian melalui kuesioner terhadap 30 siswa SMP Hidayatullah tentang permainan yang dikembangkan dan setelah diuji validasi dan reliabilitas dari kuesioner, menghasilkan beberapa kesimpulan diantaranya tampilan permainan dinilai bagus $(76.7 \%)$ dan permainan ini dapat membantu dalam mengenalkan tahap-tahap membuat bioetanol dari limbah buah $(76 \%)$.

\section{Saran}

Saran yang diberikan dalam upaya pengembangan aplikasi yang lebih baik dikemudian hari.

1. Perlu ditambahkan komponen video agar menjadi sebuah multimedia yang lebih interaktif.

2. Perlu dilakukan penambahan fasilitas pada permainan untuk memilih tidak hanya membuat bioetanol dengan bahan dasar limbah buah tetapi juga terdapat pilihan membuat bioetanol dari bahan dasar yang lain agar lebih memperkaya pengetahuan pengguna.

\section{Daftar Pustaka}

[1] Sutopo, Ariesto Hadi. Analisis dan Desain Berorientasi Objek. Penerbit J\&J Learning. Yogyakarta. 2002.

[2] Sutopo, Ariesto Hadi. Animasi dengan Macromedia Flash Berikut Action Script. Penerbit Salemba Infotek. Jakarta. 2002.

[3] Halas, John dan Roger Manvell. Film Animation Focal Press. London. 1991.

[4] Luther, ArcC. Authoring Interactive Multimedia. AP Professional. Boston. 1994.

[5] Lowery, Joseph W. Dreamweaver 4 Bible. IDG Books India. New Delhi. 2001.

[6] Asmini,Tri. Pembuatan Aplikasi Perpindahan Kalor Berbasis Multimedia Menggunakan Macromedia Flash Dan Php Mysql. Skripsi S1. Universitas Diponegoro Semarang. 2012.

[7] Nurjanah, Titin, Pembuatan Game "Memoplay" untuk Anak-anak Menggunakan Flash, Skripsi Jurusan Sistem Informasi, Sekolah Tinggi Manajemen Informatika dan Komputer Amikom Yogyakarta, 2012.

[8] Nofiantoro, Arix, Analisis dan Perancangan Game "Bermain Bersama Dito \& Dola", Skripsi Sekolah Tinggi Manajemen Informatika dan Komputer Amikom Yogyakarta, 2011.

[9] James Au, Wagner, Game Design Secrets, Wiley, 2012.

[10] Sylvester, Tynan, Designing Games : a Guide to Engineering Experiences, O'Reilly Media, 2013.

[11] Suindarti, Game Edukasi Meningkatkan Daya Ingat Anak "Bermain Bersama Dido" dengan Macromedia Director, Skripsi Jurusan Sistem Informasi, Sekolah Tinggi Manajemen Informatika dan Komputer Amikom Yogyakarta, 2011.

[12] Ir.Sutrisno, Endro, MS, Desain dan Diagnosis Pengembangan Sistem Cerdas Computer Aided Process Planning (CAPP) Untuk Estimasi Pemanfaatan Limbah Buah Menjadi Bioetanol Sebagai Salah Satu Energi Alternatif, Penelitian Unggulan Fakultas Teknik, Universitas Diponegoro, Semarang, 2012

[13] Sutopo, Ariesto Hadi. Multimedia Interaktif Dengan FLASH. Penerbit Graha Ilmu. Yogyakarta. 2003.

[14] Sugiyono. Metode Penelitian Kuantitatif, Kualitatif, dan $R \& D$. Alfabeta. Bandung, 2010.

[15] http://bahasa.kemdiknas.go.id/kbbi/index.php diakses tanggal 26 April 2013, 00.10 WIB.

1) Mahasiswa Sistem Komputer UNDIP

2) Dosen Sistem Komputer UNDIP 


\section{Biodata Penulis}

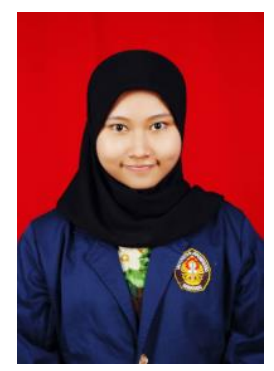

Nurul Arifa, lahir di Kebumen 08 September 1991. Telah menempuh pendidikan dasar di SDN 05 Bumirejo Kebumen. Melanjutkan ke SMP Negeri 1 Kebumen, dan meneruskan Pendidikan tingkat atas di SMA Negeri 1 Kebumen, lulus tahun 2009. Dari tahun 2009 sampai saat ini tengah menyelesaikan pendidikan Strata Satu di Program Studi Teknik Sistem Komputer, Universitas Diponegoro, Semarang, Indonesia Angkatan Tahun 2009.

Menyetujui,

Dosen Pembimbing I

Dr. R Rizal Isnanto, S.T., M.M., M.T.

NIP. 197007272000121001

Dosen Pembimbing II

Dr. Oky Dwi Nurhayati, S.T., M.T.

NIP.197910022009122001 